\title{
Sustainable finance for sustainability: a case study analysis
}

\author{
Naufal D. Adam ${ }^{1}$ and Desi Adhariani ${ }^{1, *}$ \\ ${ }^{1}$ Department of Accounting, Faculty of Economics and Business, Universitas Indonesia
}

\begin{abstract}
This study analyses the philosophical reasons behind the implementation of sustainable finance in ABC Bank in Indonesia based on parameters developed by previous research. The parameters consist of the theory of the firm, human nature of economic actors, ownership paradigm, and ethical framework. The case study approach is supported by primary and secondary data through interviews with managers and analysis of the company's related reports and documents. The results confirm the parameters of sustainable finance implementation in ABC Bank, indicating the advanced movement made by the bank relative to the other counterparts to accommodate the issue of sustainability on the financial system.
\end{abstract}

\section{Introduction}

In order to achieve a better and more sustainable future, as stipulated in the Sustainable Development goals, every party needs to play their part including business party in supporting the achievement of this vision. One of the key role that can be played by business is through the sustainable finance.

The concept of sustainable finance has been evolved as awareness of the impact of economic activities on the environment is emerging. This awareness began to appear at the end of the 1990 era when world leaders, international organizations, and various nongovernmental organizations (NGOs) at that time often discussed economic and environmental issues at high-level meetings such as global conferences [1]. Rio de Janeiro 1992 Earth Summit is one example of a meeting held by world leaders at that time to discuss environmental issues. The meeting eventually created one of the first steps in applying the concept of sustainable finance, namely the establishment of UNEP-FI.

UNEP-FI is a form of collaboration between UNEP, an institution under the United Nations (UN) which focuses on environmental conservation efforts, with more than 200 financial institutions around the world forming the partnership. UNEP-FI has a role in raising awareness of the financial industry on environmental issues and increasing the participation of the financial industry in funding environmental conservation efforts. This is done in order to encourage the contribution of the financial industry in solving existing environmental and social problems.

UNEP-FI is well-known as one of the institutions that initiated and developed the Principle of Responsible Investment (PRI), a group of principles that can be used by investors

\footnotetext{
*Corresponding author: desi.adhariani@ui.ac.id
} 
to take into account the impact on the natural and social environment in their economic activities. PRI has 6 (six) basic principles, which contain guidance that investors will:

a. Consider ESG (Environmental, Social, and Corporate Governance) issues in company investment decisions.

b. Include ESG issues in policy making and corporate economic activities.

c. Request reporting on ESG issues on other parties who will receive investment from the company.

d. Encourage industry application and understanding of the basic principles of PRI.

e. Collaborate to support the success of applying the basic principles of PRI.

f. Report on the company's activities and the process of applying the basic principles of PRI. Until 2018, PRI has been implemented by 1,925 financial institutions in 66 countries around the world. In Indonesia alone, there have been 5 (five) companies in the financial industry that have implemented PRI. In addition to preparing the PRI, to continue to increase support for the implementation of the concept of sustainable finance in particular, in 2017 UNEP through UNEP-FI in collaboration with World Bank issued a Roadmap for A Sustainable Financial System, a roadmap that aims to describe an integrated approach that can be used by all parties related to the financial sector to accelerate the adoption of the concept of sustainable finance.

In addition to UNEP-FI, there are many other international institutions that actively encourage the adoption of the concept of sustainable finance. One of the other international institutions is IFC. IFC (International Finance Corporation) is an international organization affiliated with the World Bank that plays a role in providing investment, loans, and consultations to companies in developing countries. IFC's financial products are targeted at the private sector in developing countries that aim to drive the economy in the country.

Unlike the awareness and the rapid development of sustainable finance at the global level, in Indonesia itself, the concept of sustainable finance has not been widely known both in society in general and in the business world in particular. This can be seen from the absence of regulations governing the application of the concept of sustainable finance and economic activities carried out by Indonesian companies that still use traditional financial approaches alone. This can be seen from the low number of Financial Services Institutions and Issuers that publish sustainability reports, which is in the range of $9 \%$ [2].

The low understanding of the concept of sustainable finance can also be seen from the low number of academic journals and conferences in Indonesia that specifically discuss the concept of sustainable finance. This is inversely proportional to world conditions, where discussions and debates on the concept of sustainable finance have been discussed for a long time in the international arena [3]. Varble [4] discusses how companies in developing a new product must consider environmental and social factors to complement traditional financial factors such as profit levels and sales potential. Orpen [5] discusses the increasing pressure from the community that companies take into account social and environmental aspects and not focus on profit alone. Starik \& Rands [6] discussed how environmental conservation efforts must be integrated into the decision-making process by company management.

On the other side, there is also academic research that does not support the concept of sustainable finance. Milne \& Gray [7] argued that the achievement of the three financial, social and environmental aspects at the same time is something that is impossible and cannot be achieved by management. Orts \& Strudler [8] argues that companies that try to fulfill too many interests will ultimately not be able to meet the interests of any party, because in the end there will always be conflicts of interest between the parties concerned. Both of these studies are a few examples of parties who do not agree with the concept of sustainable finance.

It was this debate that pushed this research to take place. This research is expected to be one of the drivers so that research on the concept of sustainable finance in Indonesia becomes 
more and more profound. For this reason, this study tries to analyze the application of the concept of sustainable finance to financial service institutions by using $\mathrm{ABC}$ Bank as a case study; especially in analyzing the philosophical reason behind the decision to take the sustainable finance pathways in the company's operation. ABC Bank is one of the Financial Services Institutions that have compiled a sustainability report and has become one of the first eight banks to formulate a Sustainable Financial Action Plan in accordance with the new regulations that have been approved by the Indonesia Financial Services Authority.

This study uses the parameters presented by Soppe [9] as the basis of research. According to Soppe [9], there are four parameters that determine the level of corporate financial sustainability, namely the theory of the firm/goal variables, the human nature of economic actors, the ownership paradigm, and the ethical framework. Soppe [9] uses these 4 (four) parameters to distinguish the concept of sustainable finance from traditional financial concepts.

\section{Sustainable finance parameters}

\subsection{Corporate theory}

The corporate theory explains the fundamental reasons for a project [10]. The reason for the establishment of a company will affect the nature of the company. There are three (3) approaches to corporate theory discussed in Soppe [9]. The three theories are models of private property, social institution theory, and contractual theory.

The first theory is the private property rights model. This theory believes that companies as owners of resources have the right to use, benefit, and get the benefit of all the things that come from these resources [11]. In a neoclassical view, the company is a collection of investment project investments that aim to get the maximum profit (the company is also considered to have the right to use the resources it has to benefit from its economic activities. The second theory is the social institution theory, which argues that the right to have power in a company is a privilege given by the state so that there are aspects of public interest in each company. The third theory is the contractual rights theory, which argues that the company becomes an extension of the government in creating general welfare.

Unlike traditional finance that uses property right models, companies that implement sustainable finance are more likely to use contractual right theory. Considering that a company is supported by various sources (not just financial aspects), it is fitting for the company to include these aspects in the company's objectives and not just focus on achieving financial aspects. In the concept of sustainable finance itself, there are social and environmental aspects that are taken into account in corporate decision making. This is what is referred to as the Triple Bottom Line.

\subsection{Human nature of economic actor}

The concept of sustainable finance also has its view of human behavior. Sustainable finance enhances the view of humans as economic actors in human beings as moral, economic actors. The concept of sustainable finance views humans as Moral Economic Man, meaning that a human being will behave rationally, but will continue to work with other parties to achieve common goals.

In its application, it can be seen that the Moral Economic Man theory can describe the behavior of a company that applies the concept of sustainable finance. This can be seen from the company's decision to remain concerned about environmental and social aspects through CSR programs even though CSR programs have been shown to have a negative influence on 
the company's long-term benefits because the use of resources in CSR programs should be used in other activities that can bring benefits to the company [12].

\subsection{Ownership paradigm}

In the concept of traditional finance, shareholders are the only party that can become a residual claimant. In the concept of sustainable finance, all stakeholders are equally entitled to become residual claimants because they share the residual risk. This concept is called a multi-stakeholder risk bearer, which is when each of the parties involved has a part of the company's risk; the profits that the company receives must be attributed to all parties who have the risk.

\subsection{Ethical framework}

In traditional finance, companies use an immoral manager approach. This approach allows companies to maximize revenue without regard to the impact experienced by other parties. Companies that apply traditional financial concepts are too focused on the concept of utilitarianism so that the decision-making process only focuses on profit consideration without the intervention of ethical and moral values that exist in society. In contrast to traditional financial concepts, in sustainable finance, the company has its approach to moral obligations, namely through the concept of virtue ethics, which was developed by Socrates, Plato, and Aristotle. Virtue Ethics suggested that ethics should not be based on rules, laws, or principles that exist in society but derived from the commendable nature that comes from within the individual itself [9]. As an illustration, when we say honestly because there is an awareness that saying honestly is a commendable thing, at the same time we also strengthen the value of honesty itself.

\section{Research method}

This study analyzed the application of sustainable finance at ABC Bank using four (4) criteria from Soppe [9]. The research was conducted by determining several questions in advance which are the results of the derivation of several theories and previous studies. To analyze the answers, this study uses qualitative methods and case studies. The case study was chosen to be able to know in depth how the implementation of sustainable finance at ABC Bank.

The data used in this study is the primary data obtained through interviews with the ABC Bank managers as an object of a case study or OJK (Indonesian Financial Services Authority) as a regulator. In addition, this study also uses secondary data by looking at the information available on sustainability reports, annual reports, and related regulations such as OJK regulations, BI (Indonesia Central Bank) regulations, and other related laws.

\section{Results and discussion}

In this section, the business activities of $A B C$ are analyzed to determine whether or not their business operation has been in line with the parameters set by Soppe [9]. The first parameter to be analyzed is the Theory of the Firm. In order to be considered successful in fulfilling the first parameter, a firm must showcase its awareness that the company was not founded solely to gain profit. To entertain this concern, the first thing to be analyzed is the reason for the establishment of a company. As a State-Owned Enterprise (SOE), the reason for the establishment of SOEs is already regulated according to the applicable legislation, namely the Law on State-Owned Enterprises (No. 19/2003). 
The existence of regulations for SOEs indicates that $\mathrm{ABC}$ as one of the SOEs already has a fundamental reason for implementing sustainable financial concepts. Such regulation is a government effort to ensure that making profit aspect is not the only goal firms have in mind. In addition, the company's operational objectives are also contained in the Shareholder Aspiration Letter (SAL), a written letter from shareholder (in this case the Government of the Republic of Indonesia represented by the Minister of SOEs) to the Board of Directors regarding assumptions that should be used in the preparation for the budgeting as well as all targets to be achieved be it from the financial aspect, social aspect, and the environmental aspect.

As a follow up for those two aforementioned documents, ABC's business operations are not solely done for the sake of profit. This can be seen from the firm's decision to increase its presence in remote areas even though it's not necessarily profitable. $\mathrm{ABC}$ has also deployed agents of $\mathrm{ABC}$ which became a firm representative in providing banking services to people in remote areas which were unable to access banking services before. This shows that $\mathrm{ABC}$ has been actively trying to fulfill its purpose to contribute to the national economic development by providing services finance for people in remote areas. In addition to encouraging financial inclusion, $\mathrm{ABC}$ 's concern for social and environmental aspects can also be seen in the Partnership and Community Development Program aimed at improving people's welfare and nature conservation.

The second analysis is about the Human Nature of Economic Actor. To be considered successful in fulfilling the second parameter, a company must show that in the decisionmaking process, the firm does not solely use profit as an absolute parameter, instead of the firm should also consider the impact for other parties who may be affected by the decision taken by the company.

To assess this parameter, the first thing to analyze is the company's business decisionmaking process. $\mathrm{ABC}$ has integrated the assessment of social and environmental impacts into the decision-making process, take the firm crediting process as an example. In considering credit application by a prospective client, $\mathrm{ABC}$ won't use the client's rate of return and financial capacity as the only determinant factor in the decision-making process. Instead, $\mathrm{ABC}$ will also consider various risks that must be borne by $\mathrm{ABC}$ and related parties while also considering the impact of client's business activities on social and environmental aspects.

In order to do the aforementioned parameter, $\mathrm{ABC}$ has a Corporate Banking Credit Guideline Book I, a credit requirement for its prospective customers so that the credit decision also considers the customer's efforts to preserve the environment and their responsibility for all the environmental and social impacts that will arise. This is done by requiring prospective customers to include documents such as AMDAL (Analysis of Environmental Impact) in their credit applications. Specifically, for companies with the potential of having a significant impact on the environment, $\mathrm{ABC}$ will also only process their application only if the firm has passed the Company's Environmental Performance Rating Program (PROPER) by the Ministry of Environment and Forestry, an assessment by said ministry to assess the company's compliance with the applicable environmental regulations in Indonesia.

The third parameter is Ownership Paradigm. In order to be considered successful in fulfilling the third parameter, a company must showcase its understanding that the interests of shareholders are not the only interests to attend. To be able to assess this parameter, the first thing to be analyzed is the vision statement of the company. Based on the financial statements of 2017, the vision of $\mathrm{ABC}$ is to become a financial institution that excels in service and performance. $\mathrm{ABC}$ also explains excellence in services means that $\mathrm{ABC}$ can be a partner for its customers by providing comprehensive financial services. From the firm vision statement, it can be seen that ABC doesn't solely focus on the fulfillment of the 
interests of shareholders. ABC Bank also has various stakeholder engagement strategies for each stakeholder. This is done to ensure that $\mathrm{ABC}$ understands the interests and expectations of the stakeholders. Stakeholder engagement by ABC is different for each stakeholder.

The last parameter is the Ethical Framework. In order to be considered successful in fulfilling the last parameter, a company must show that the company uses virtue ethics theory as the basis of moral judgment on a decision taken by the company. There are several ABC policies that showcase its characteristic as a company that implements virtue ethics. For example, $\mathrm{ABC}$ has shown awareness that $\mathrm{ABC}$ is a part of a larger community and has its role in society. This is why $\mathrm{ABC}$ often support the effort of nature conservation and develop the economy through CSR program which has been explained previously. This illustrates that $\mathrm{ABC}$ is engaged as a part of the community and continuously strives to benefit society in accordance with the capacity of $\mathrm{ABC}$ as a company.

In addition to that, $\mathrm{ABC}$ has also been active in trying to encourage its employees to behave virtuously both in a business context and in the daily life context. For that, $\mathrm{ABC}$ has compiled two guides, namely Code of Conduct and company principles. The ABC Code of Conduct contains 14 points set up to regulate the relationship between $\mathrm{ABC}$ employees and all stakeholders in conducting business activities. Meanwhile, $\mathrm{ABC}$ principle is work culture and behavior expected from all employees of $\mathrm{ABC}$. All of the guidance above also becomes the basis of $\mathrm{ABC}$ to encourage all employees from the board of directors, management, to employees in general to always behave virtuously. Something also noteworthy is the fact that $\mathrm{ABC}$ also considers the integrity of new employees in the recruitment process. This is because $\mathrm{ABC}$ believes that people who have a good personality in everyday life will also behave well in business activities. New employees with good personality are also expected to absorb and internalize all of the ethical guidance more easily.

Below is the summary of the sustainable finance implementation in $\mathrm{ABC}$ based on Soppe [9].

Table 1. Parameters and sustainable finance in $\mathrm{ABC}$.

\begin{tabular}{|c|l|l|}
\hline No. & \multicolumn{1}{|c|}{ Parameters } & \multicolumn{1}{|c|}{ Implementation } \\
\hline 1 & Theory of the firm & $\begin{array}{l}\text {-Corporate vision and mission } \\
\text {-Various company's programs }\end{array}$ \\
\hline 2 & $\begin{array}{l}\text { Human nature of } \\
\text { economic actor }\end{array}$ & $\begin{array}{l}\text {-Decision-making process } \\
\text {-Credit requirement based on the social and } \\
\text { environmental aspect }\end{array}$ \\
\hline 3 & Ownership paradigm & -Stakeholder engagement \\
\hline 4 & Ethical framework & -Implementation of virtue ethics \\
\hline
\end{tabular}

Taking into account all of the explanation above, it can be concluded that $\mathrm{ABC}$ has implemented the concept of virtue ethics. This can be seen from the active efforts of $A B C$ to consistently continue to show a virtuous characteristic both in decision-making and on policies and regulations set by $\mathrm{ABC}$ for its employees. After assessing the implementation of sustainable finance in $\mathrm{ABC}$ with all parameters set by Soppe [9], it can be concluded that $\mathrm{ABC}$ has implemented the concept of sustainable finance. This is the result of the analysis of the entire set of parameters which indicates that $\mathrm{ABC}$ is a company that has applied the concept of sustainable finance based on a set of parameters set by Soppe [9]. It is recommended that $\mathrm{ABC}$ continues the implementation of sustainable finance in the future mandatorily to follow the regulation as well as voluntarily as indicated in the achievement of the parameters. 


\section{Conclusion}

Based on all analysis and discussion that has been done in the previous chapters, it can be seen that $\mathrm{ABC}$ has fulfilled all parameters set by Soppe [9]. In the Theory of the Firm, ABC has shown the implementation of triple bottom line concept, as the company acknowledged that they're not founded solely to gain profit, but also to improve social welfare, preserve the environment, and contribute to development in Indonesia. While in the Human Nature of Economic Actor, $\mathrm{ABC}$ has shown the characteristic of moral, economic man, because, in the decision-making process, the company takes into consideration the impact of its business decisions for society and the environment alongside its economic rationale.

In the Ownership Paradigm, ABC has demonstrated the implementation of stakeholder theory by establishing nine stakeholders of the company whose respective interests must be fulfilled by the company and the shareholders are not the only party whose interests must be fulfilled. Meanwhile, in the Ethical Framework, ABC has shown that ABC is a company that has a drive from within the company to become a company that behaves virtuously. It is seen as $\mathrm{ABC}$ always tries to behave virtuously in any condition by using various guides prepared by the company.

\section{References}

1. J. Davidson, Dev. in Prc. 2, 3 (1992)

2. OJK (Otoritas Jasa Keuangan), Peraturan Otoritas Jasa Keuangan Nomor 51 /POJK.03/2017 (2017)

3. D. Cash, SSRN (July 2017)

4. D. Varble, J. of Mkt. 36, 4 (1972)

5. C. Orpen, C. J. of Bus. Eth. 6, 2 (1987)

6. M. Starik, G. Rands, The Acd. Of Mgt. Rev. 20, 4 (1995)

7. M. Milne, R. Gray, J. of Bus. Eth. 118, 1 (2013)

8. E. Orts, A. Strudler, J. of Bus. Eth. 88, 4 (2009)

9. A. Soppe, J. of Bus. Eth. 53, 1 (2004)

10. R. Lozano, A. Carpenter, D. Huisingh, J. of Cln. Prd. 106, 430 (2015)

11. G. de Avila Monteiro, D. Zylbersztajn, Stg. Org. 10, 4 (2012)

12. A. Bhandari, D. Javakhadze, J. of Cor. Fin. 43, 354 (2017) 